\title{
IAMJ
}

INTERNATIONAL

AYURVEDIC

MEDICAL JOURNAL

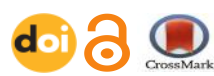

Research Article

ISSN: 2320-5091

Impact Factor: 6.719

\section{AN OBSERVATIONAL STUDY ON ASSESSMENT OF PAIN THRESHOLD IN TRIVIDHA SATWABALA}

\author{
Anushree M. S ${ }^{1^{*}}$, Soumya Saraswathi.M², R. Vidyanath ${ }^{3}$ \\ ${ }^{1}$ PG Scholar, Department of Ayurveda Samhita and Siddhanta, Alva's Ayurveda Medical College, Moodbidri, \\ Karnataka, India \\ ${ }^{2}$ Professor, Department of Samhita and Siddhanta, Alva's Ayurveda Medical College, Moodbidri, Karnataka, India \\ ${ }^{3}$ Professor and HOD, Department of Ayurveda Samhita and Siddhanta, Shri Dhanwantry Ayurvedic \\ College and Hospital, Chandigarh, India
}

Corresponding Author: anushree.ms92@gmail.com

https://doi.org/10.46607/iamj1409102021

(Published Online: October 2021)

Open Access

(C) International Ayurvedic Medical Journal, India 2021

Article Received: 09/10//2021 - Peer Reviewed: 18/10/2021 - Accepted for Publication: 19/10/2021

Check for updates

\begin{abstract}
Introduction: 'Purusha' the sentient being in Ayurveda is formed by the combination of Satwa (Mind), Atma (Soul) and Shareera (Body). Among these, paramount importance has been given to the role of the mind in both health and diseased states. In the present study, the term Satwa has been used to denote Satwabala or the psychic strength of an individual. The assessment of Satwabala is an important part in examination of the patient and while planning the treatment. The interrelationship of mind and body is well explained in Ayurveda. The pain inflicted on one's body has influence on his mind. Some people feel pain more intensely than others and some tolerate it so much more than others. Thus, quantification of pain with reference to psychic strength is essential for diagnostic and pain monitoring purposes in clinical practice. Aim and Objectives: The study was carried out with an aim to assess the Pain threshold in the form of Pressure Pain Threshold [PPT] and the Pain intensity in the form of the Visual Analog Scale [VAS] in three types of Satwabala. It was hypothesised that there could be a positive relation between Satwabala and Pain threshold. Methods: For the objective assessment of Pressure Pain Threshold a simple handheld pressure Algometer has been used. For the subjective measurement of experimental pain, Visual Analog Scale was used. Further, the Satwa of participants was assessed using a standard questionnaire. Results: The results
\end{abstract}


suggested that in people between the age group of 18-40 years, there exist a statistically highly significant positive correlation between Satwabala and Pain threshold with $\mathrm{P}<0.01$.

Keywords: Satwa, Satwabala, Pain threshold, Pressure Pain Threshold, Visual Analog Scale.

\section{INTRODUCTION}

Ayurveda takes into consideration every aspect of life viz. Satwa (Mind), Atma (Soul) and Shareera (Body)

${ }^{[1]}$. Out of these, the Satwa which is also being called Manas (Mind) ${ }^{[2]}$ occupies the very first place. It can also be related to the term mental strength or mental stamina, psyche or inborn character of a person. $\mathrm{Hu}-$ man beings are classified into three categories depending upon their Satwabala (psychic strength) viz, Pravara Satwa, Madhyama Satwa and Avara Satwa (Superior, mediocre and inferior mental faculties respectively) ${ }^{[3]}$. In the classical text of Ayurveda Charaka Samhitha, 'Dashavidha Pareeksha' (Ten important factors for examination of a patient) has been told ${ }^{[4]}$. The purpose of this examination is to obtain knowledge relating to the strength of the individual and the intensity of morbidity. Therefore, to ascertain his strength; specifically, the mental strength, the patient should be examined with reference to his mental faculties which is called Satwa Pareeksha. An evaluation of mental stamina is also done to determine whether it is superior, medium or inferior in a person to his tolerance and adjusting capacity with respect to pain or odd situations.

Pain/Tenderness is the major symptom/sign elicited in almost all patients. The perception of pain differs among individuals and are affected by environmental and psychological factors at times. Therefore, its accurate evaluation is important in the diagnostic procedure. In clinical practice, digital pressure palpation is usually used to locate and assess the pain. However, this method is difficult to quantify and standardize the pain. The Visual Analog Scale [VAS] and Pressure Algometry are the commonly used techniques to quantify pain.

Pain Threshold is described as the lowest intensity of a painful stimulus at which the individual perceives pain. Pressure, Thermal, Electrical and LASER are some of the commonly used techniques to induce experimental pain in threshold assessment studies. Among these, assessment of pain threshold by inducing pressure is the most affordable and convenient method and thus selected for the present study. The Pressure Pain Threshold [PPT] is the point at which a subject perceives pain on the application of a pressure stimulus. Pressure algometry is a technique used to objectify this PPT. This is a well-known validated method to induce acute experimental pain. The Visual Analog Scale (VAS) is a pain rating scale widely used as a measure of subjective pain intensity.

To test and validate the fundamental concepts, the development of parameters on a scientific basis is a need of time. Keeping this in view, this study is undertaken to explore furthermore the concept of Satwa with special reference to pain threshold in healthy human subjects. The study is also focused to review the role of psychological factors in the experience of pain. Here, the psychic strength or the tolerance of the individual is assessed and studied by using the pain threshold as a parameter.

\section{MATERIALS AND METHODS:}

A cross-sectional survey was conducted among 150 healthy volunteers within the age group of 18 to 40 years who were recruited from in and around the area of Moodbidri Taluk, D.K District, Karnataka, India. Persons who were on medication 24 hours prior to experimental pain recording were excluded from the study.

Experimental pain assessment: First their Pressure Pain Threshold was recorded with the help of an Algometer. Total 6 tender points located bilaterally on the upper trapezius, the extensor carpi radialis and first dorsal interosseous muscles were assessed in identical sequence in all subjects. Readings were taken at each of the points (in $\mathrm{kg} / \mathrm{cm}^{2}$ ) and the average of these readings was considered for analysis. Immediately after 
Algometry, participants' Visual Analog Scale [VAS] scores were recorded.

Assessment of Satwa: Further, the Satwa of participants was assessed using a standard questionnaire and according to the obtained scores they were graded as Pravara, Madhyama and Avara Satwa respectively. The values of PPT and VAS are then compared with the respective Satwa of the individuals.

Statistical Analysis: The data collected were analysed using descriptive statistics, frequencies, Chi-square test, cross-tabulations, Spearman's Rank order Correlation, Mann-Whitney Rank Sum Test and Kruskal Wallis one-way ANOVA on Ranks.
RESULTS: Among 150, the total number of volunteers in the Pravara, Madhyama and Avara Satwa categories were 50 each. A maximum of $46 \%$ of volunteers were having PPT ranging from $1-2 \mathrm{~kg} / \mathrm{cm}^{2}$. A minimum of $8 \%$ of volunteers had PPT ranging from $3-4 \mathrm{~kg} / \mathrm{cm}^{2}$. Here the low pain threshold is $0-1 \mathrm{~kg} / \mathrm{cm}^{2}$ and the High pain threshold represents PPT ranging from $3-4 \mathrm{~kg} / \mathrm{cm}^{2}$. A maximum of $33.33 \%$ of volunteers reported a VAS score indicating moderate pain. A minimum of $15.33 \%$ of volunteers reported a VAS score indicating severe pain.

Graph 1: Distribution of volunteers as per Pressure Pain threshold [PPT]

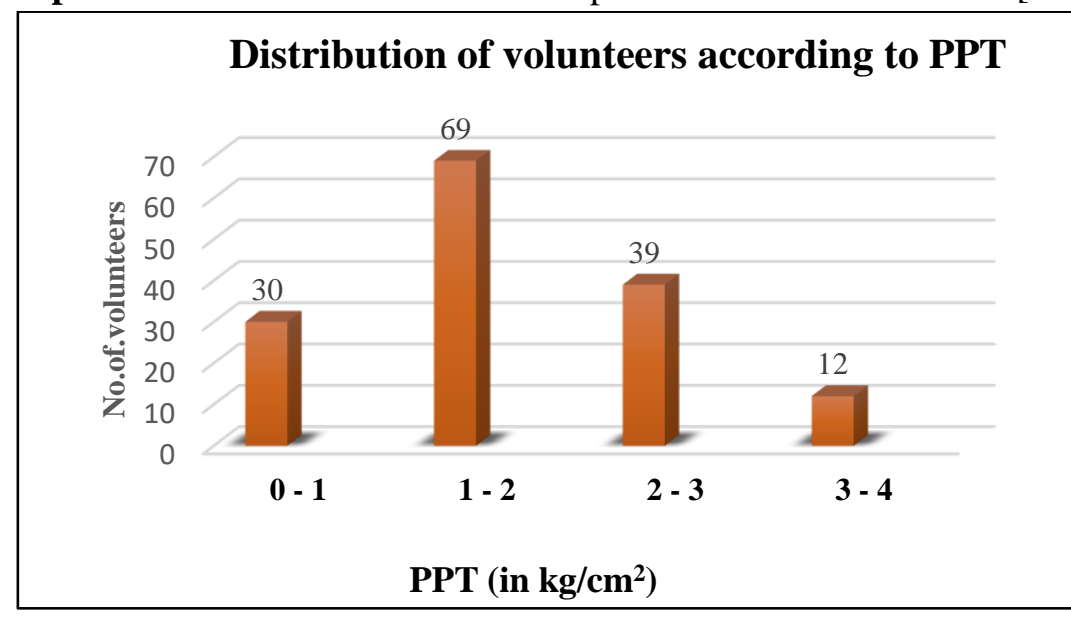

Graph 2: Distribution of volunteers according to Visual Analog Scale [VAS]

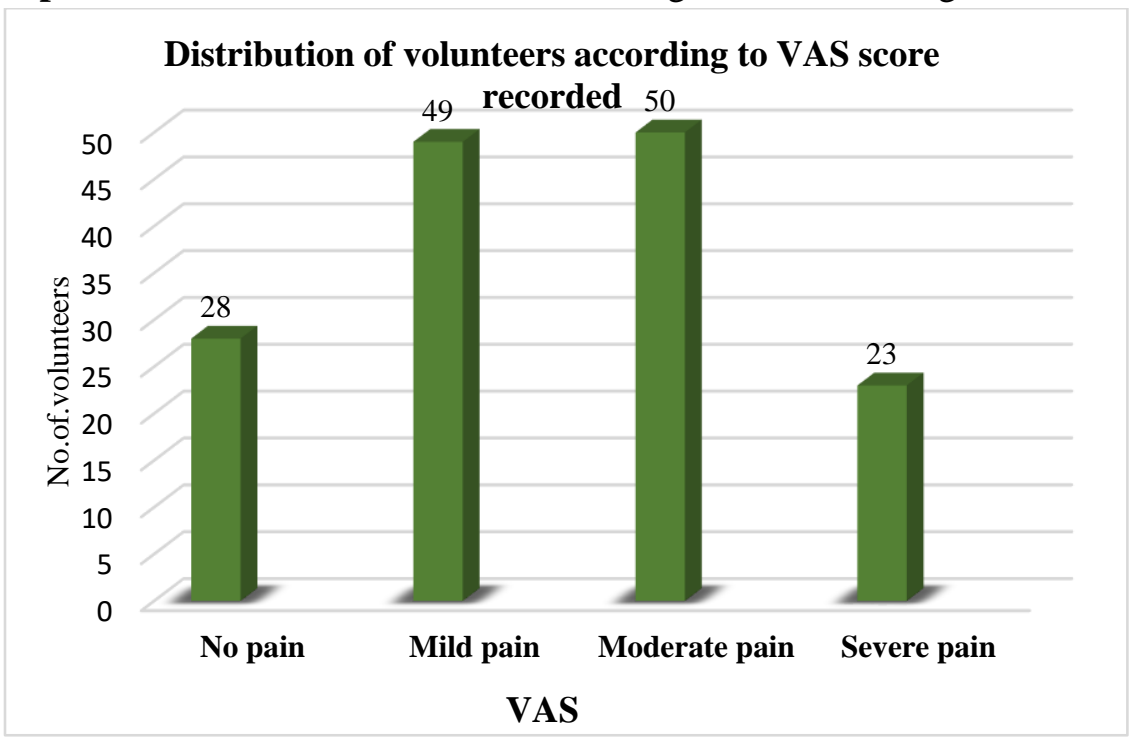




\section{Relation between Satwa and Pressure Pain Thresh-} old:

The mean PPT obtained was $1.82 \pm 0.76 \mathrm{~kg} / \mathrm{cm}^{2}$. The maximum and minimum values of PPT observed in
Avara Satwa were $2.0 \mathrm{~kg} / \mathrm{cm}^{2}$ and $0.6 \mathrm{~kg} / \mathrm{cm}^{2}$ respectively, that of Madhyama Satwa were $2.5 \mathrm{~kg} / \mathrm{cm}^{2}$ and $0.9 \mathrm{~kg} / \mathrm{cm}^{2}$ respectively and that of Pravara Satwa were $3.2 \mathrm{~kg} / \mathrm{cm}^{2}$ and $2.1 \mathrm{~kg} / \mathrm{cm}^{2}$ respectively.

Table 1: Results of Satwa and Pain threshold

\begin{tabular}{|l|l|l|l|}
\hline SATWA & Range of Pressure Pain Threshold [PPT] & Mean PPT $\left(\mathrm{in} \mathrm{kg} / \mathrm{cm}^{2)}\right.$ & S. D \\
\hline Pravara & $2-4 \mathrm{~kg} / \mathrm{cm}^{2}$ & 2.74 & 0.35 \\
\hline Madhyama & $1-3 \mathrm{~kg} / \mathrm{cm}^{2}$ & 1.64 & 0.33 \\
\hline Avara & $0-2 \mathrm{~kg} / \mathrm{cm}^{2}$ & 1.07 & 0.24 \\
\hline
\end{tabular}

Table 2: Descriptive statistics of Pressure Pain Threshold [PPT]

\begin{tabular}{|l|l|l|l|l|l|}
\hline Descriptive Statistics & Maximum & Mean & Std. Deviation \\
\hline PPT & N & Minimum & Man & .8000 & .7626459 \\
\hline
\end{tabular}

The Pearson Chi-square test suggests that there is a statistically highly significant strong association between Satwa and Pressure Pain Threshold [PPT] with $\mathrm{P}<0.01$. Spearman's rank-order correlation suggests that there is a statistically highly positive correlation between Satwa and PPT. This indicates a strong positive relationship between the individuals Satwa and
PPT obtained. That is, the higher the Satwa, the higher is the PPT also; and vice versa. There is a statistically highly significant difference in the mean PPT between the three types of Satwa as determined by one-way ANOVA. A Tukey post hoc test revealed significant differences in mean PPT between all the three groups of Satwa.

Graph 3: Relation between Satwa and Pressure Pain Threshold

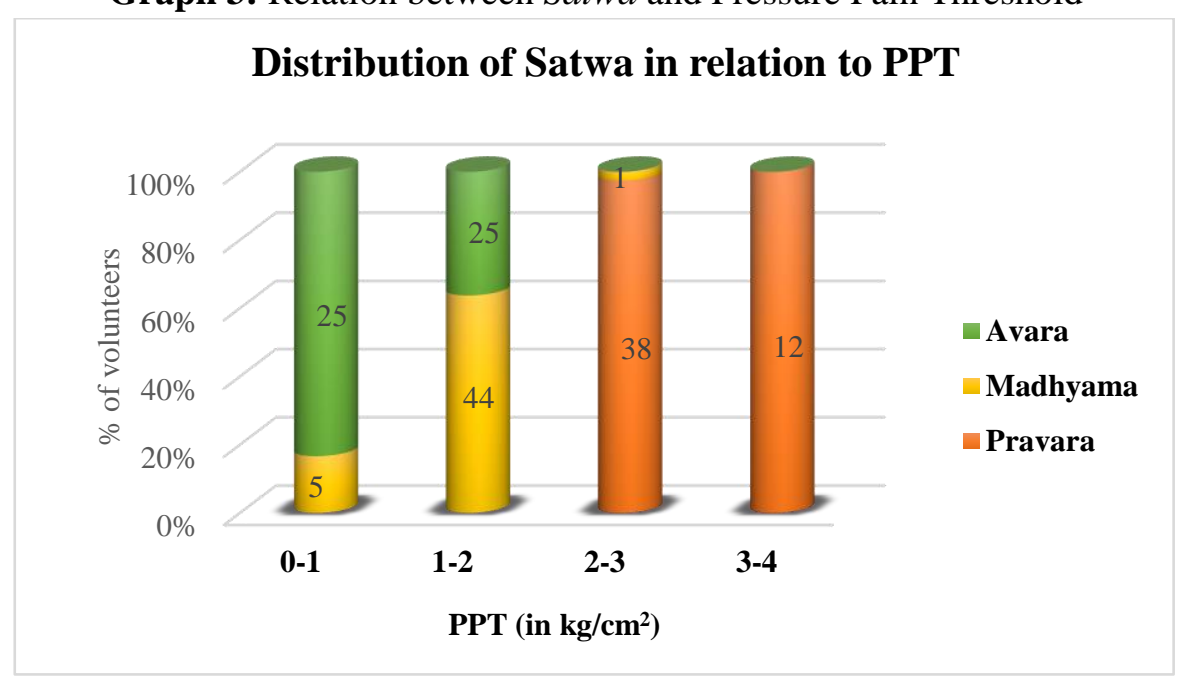

\section{Relation between Satwa and VAS score:}

The spearman's rank-order correlation suggested a negative correlation between Satwa and VAS. This in- dicates that there are no significant correlations between the individuals Satwa and their intensity of pain reported (VAS score). 
Graph 4: Relation between Satwa and VAS score

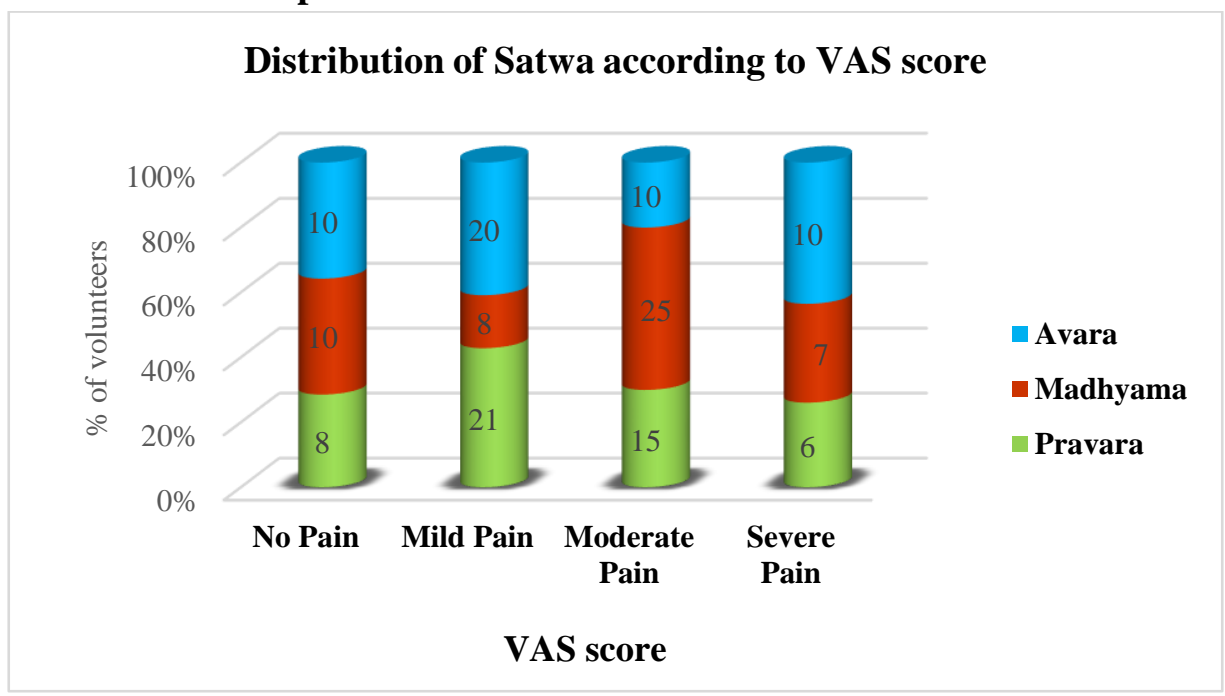

\section{DISCUSSION}

Satwa as Manas: Only Acharya Charaka has given a detailed explanation about the classification of Satwa according to Bala (strength). As explained in the context of Dashavidha Pareeksha in Charaka Samhitha, the term Satwa is nothing but the Manas ${ }^{[5]}$. When the term Manas is used in any context, it is Trigunatmaka (having Satva, Raja and Tamo Guna). To highlight the significance of Satwa Guna, the purest form of Manas, the term Satwa is utilized in this context rather than the term Manas.

In Susrutha Samhitha, Sutrasthana $35^{\text {th }}$ chapter, Satwa is defined as that capacity of the mind which does not cause frustration (agony, misery) at times of sorrow, joy, anger, fear etc. In the same context, the commentator Acharya Dalhana describes Satwa as Manobala (psychic strength), wherein he says that the persons with a predominance of Satwa guna will have Uttama Manobala (superior mental strength), those with a predominance of Rajo guna will have Madhyama Manobala (moderate mental strength) and the persons with Tamoguna predominance will have Manodaurbalya. (Weak mental strength).

The Satwabala was referred to as Utsaha or Virya by Chakrapani. The Nibandha Samgraha commentary mentions the opinion of Acharya Chakrapani that Satwabala or Manobala can be increased by increasing the Satva guna (i.e., Satwa utkarsha or Satwa guna utkarsha $)^{[6]}$. From these references, it is understood that Satwa is Manas. And Satwabala is nothing but Manobala or psychic strength.

Satwa has genetic attribute as it is inherited at the time of conception and therefore termed as 'Sahaja Satwabala' and this part of the individual gets nurtured in the womb especially by the influence of 'Satvavaisheshikara bhavas ' [7] and by the influence of one's own experience' during infancy, childhood and adolescence. In context to these references, it can be concluded that; due to genetic reasons or the general upbringing, different persons display different categories of mental stamina.

\section{Age and Sex relation with Pain threshold:}

The study consisted of volunteers between the age group of 18-40 years with a mean age of 28.39 years. Age and sex are the main non-modifiable biological factors that affect pain. In this study, there was no increase in pain threshold observed with an increase in age. Females have been found to have significantly lower pain threshold levels than males. $92 \%$ of males showed a higher pain threshold ranging from 3-4 $\mathrm{kg} / \mathrm{cm}^{2}$. Differences in pain sensitivity response between males and females could be influenced by the following factors.

Biological factors: The sex differences in Pain experience could be due to the influence of sex hormones (oestrogen and progesterone) in females. As the levels 
of these two hormones vary across the menstrual cycle there is a variation in pain reaction. From the clinical point of view, studies have established that there is an increase in pain sensitivity at times of the lowest oestrogen or rapidly fluctuating oestrogen in normally menstruating women ${ }^{[8]}$. Psychological and social factors such as stress and anxiety may also influence sex differences in pain response.

\section{Exercise \& Pain threshold:}

The participants who followed regular exercise showed significantly higher pain thresholds and participants who were not doing exercise were observed to have a lower pain threshold. It was observed that; in healthy subjects, exercise increases thresholds for experimentally induced pain. According to modern science, physical activity enhances or maintains physical fitness, which may be the cause for increased pain threshold levels of the individual.

Acharya Charaka describes the effort which produces stability and strength in the body as Vyayama (Exercise). It provides the benefit of 'Karma Samarthya' (ability to work). This also can be understood as the ability to bear troubles ${ }^{[9]}$. According to Sushrutha in individuals practising daily Vyayama, there is physical development, compactness of body parts, firmness, and optimum immunity ${ }^{[10]}$.

\section{Relation between Satwa and Pain threshold:}

The Pressure Pain Threshold [PPT] indicates the minimum point at which a person experiences pain sensation. The low pain sensitivity indicates a higher pain threshold and high pain sensitivity indicates a lower pain threshold. An individual's mental status is one of the main factors which may influence the experience of pain. This study yielded results indicating a strong association or relationship between individual's Satwa and Pressure Pain Threshold [PPT]. There is a statistically highly significant positive correlation between Satwa and Pain threshold with $\mathrm{P}<0.01$. This suggests that the higher the Satwa, the higher is the Pain threshold and vice versa.

No volunteers in the Avara Satwa category showed high PPT levels ranging from $3-4 \mathrm{~kg} / \mathrm{cm}^{2}$ or even 2$3 \mathrm{~kg} / \mathrm{cm}^{2}$, which proves that Avara Satwa people cannot tolerate more pain and are highly sensitive to pain stimuli. No volunteers in Pravara Satwa category showed very low PPT levels i.e., $0-1 \mathrm{~kg} / \mathrm{cm}^{2}$ or $1-2$ $\mathrm{kg} / \mathrm{cm}^{2}$; which proves that Pravara Satwa people can tolerate more pain than that of Avara Satwa. Whereas participants in Madhyama Satwa category showed very low to a moderate threshold to pain $\left(0-2 \mathrm{~kg} / \mathrm{cm}^{2}\right)$ and only one participant was observed to have a pain threshold of $2-3 \mathrm{~kg} / \mathrm{cm}^{2}$ but there was no volunteer in the Madhyama Satwa category who showed high pain threshold levels i.e., $3-4 \mathrm{~kg} / \mathrm{cm}^{2}$.

The research study aimed at classifying patients with chronic pain suggested a relationship between pain and psychological traits. The results suggest that the Pain threshold would be a useful tool for understanding the psychological traits of patients with chronic pain ${ }^{[11]}$. Therefore, the application of the main findings of this research study finds very much useful in clinical practices. Because the positive response of a patient to therapy is also guided by the innate positivity in the individual. The positive impact of a placebo on treatment is because of the mind. As Satwa exerts a positive or negative impact on the effect of treatment, in patients who suffer from chronic pain conditions who were most vulnerable to be Avara Satwa if their Satwabala is increased they could manage the pain much better.

\section{Relation between Satwa and VAS:}

As per the VAS scores, the Avara Satwa individuals who were supposed to be the highly sensitive group; included significantly more participants with 'NO Pain' than did the other two groups (Pravara and Madhyama). This suggests that relying only on patients reports of pain (subjective assessment) may mislead a physician in deciding treatment or medication. This analysis supports the statement of Acharya Charaka, in Vimanasthana in the context of 'Guru vyadita and Laghu vyadita' wherein it has been mentioned that the seriousness or mildness of a disease in a patient is difficult to determine. Because of the variation in mental faculties such as Pravara, Madhyama and Avara; while examining a patient only from the symptoms he says about the disease, ignorant physicians commit mistakes in deciding upon the serious- 
ness or mildness of the disease. Under such misconceptions, if wrong therapies are administered to patients, it results in aggravation of the disease ${ }^{[12]}$. Therefore, in such cases, Satwa Pareeksha is helpful to understand the severity of pain in a patient based on Satwabala (mental strength).

\section{CONCLUSION}

The study highlighted the relation between Satwa and the Pain threshold of an individual. Understanding the concept of Satwabala thus provides useful insight into the tolerance of individuals towards painful situations. It can be concluded that Satwa of the individual would be associated with and would be a good predictor of pain threshold and that low-medium-high levels of pain threshold would lead to similar levels of Satwa.

\section{REFERENCES}

1. Acharya Y T, editor. Charaka Samhita of Agnivesha, Sutra Sthana. Ch.1, Ver.46. Reprint edition. New Delhi: Chaukhamba Publications; 2018. p.11.

2. Acharya Y T, editor. Charaka Samhita of Agnivesha, Vimana Sthana. Ch 8, Ver.119. Reprint edition. New Delhi: Chaukhamba Publications; 2018. p.280.

3. Acharya Y T, editor. Charaka Samhita of Agnivesha, Sutra Sthana. Ch. 8, Ver.119. p.280

4. Acharya Y T, editor. Charaka Samhita of Agnivesha, Sutra Sthana. Ch. 8, Ver.84. p.274

5. Acharya Y T, editor. Charaka Samhita of Agnivesha, Sutra Sthana. Ch. 8, Ver.119. p.280

6. Acharya Y T, editor. Sushrutha Samhitha, Sutra Sthana. Ch.35, Ver.37. Reprint edition. Varanasi: Chaukhamba Sanskrit Sansthan; 2017. p.156.

7. Acharya Y T, editor. Charaka Samhita of Agnivesha, Shareera Sthana. Ch.8, Ver.16. Reprint edition. New Delhi: Chaukhamba Publications; 2018. p.342.

8. Resche L, Mancl L, Sherman JJ, Gandara B, Dworkin SF.'Changes in temporomandibular pain and other symptoms across the menstrual cycle'. Pain Journal.2003;106 (3): 253-61.

9. Acharya Y T, editor. Charaka Samhita of Agnivesha, Sutra Sthana. Ch.7, Ver.32. Reprint edition. New Delhi: Chaukhamba Publications; 2018. p.50.

10. Acharya Y T, editor. Sushrutha Samhitha, Chikitsa Sthana. Ch.24, Ver.40. Reprint edition. Varanasi: Chaukhamba Sanskrit Sansthan; 2017. p.489.
11. Kato, F. Abeet al. Pain threshold reflects psychological traits in patients with chronic pain: a cross-sectional study. Bio Psychosocial Med 11, 13 (2017).

12. Acharya Y T, editor. Charaka Samhita of Agnivesha, Vimana Sthana. Ch.7, Ver.3. Reprint edition. New Delhi: Chaukhamba Publications; 2018. p.257.

\section{Source of Support: Nil Conflict of Interest: None Declared}

How to cite this URL: Anushree M. S et al: An Observational Study On Assessment Of Pain Threshold In Trividha Satwabala. International Ayurvedic Medical Journal \{online\} 2021 \{cited October 2021\} Available from: http://www.iamj.in/posts/images/upload/2385_2391.pdf 